\title{
A FIRST SIMPLE MODEL FOR PERIODICALLY SELF-SURGING GLACIERS
}

\author{
By W. F. Budd \\ (Antarctic Division, Department of Science, 568 St Kilda Road, Melbourne, Victoria 3004, \\ Australia)
}

\begin{abstract}
A two-dimensional model of glacier flow is presented which includes periodical surging as a natural phenomenon for a certain class of glaciers. The input consists of the bedrock and balance profiles along the glacier, together with the ice flow properties and a frictional lubrication factor. The basal stress is determined from the condition of gross equilibrium for the whole glacier, together with the distribution of the frictional lubrication from energy dissipation along the glacier.

The difference between the basal stress and the down-slope stress of the glaciers produces longitudinal strain-rates which determine the basal sliding velocity. Since the velocity is also involved in the frictional lubrication, feed-back develops between the basal stress and sliding velocity.

For a given lubrication factor, a critical stage can be reached for which the velocity becomes sufficiently high to lower the basal stress, enough to cause very high velocities to develop. The model thus gives rise to three classes of glaciers with two modes of flow.

"Ordinary" glaciers do not have sufficient mass flux, for the given bedrock profile, to go beyond the "slow mode" in which the basal stress and velocity increase together as the glacier builds up to steady state.

"Fast" glaciers have sufficient flux to remain continuously in the "fast mode" with high velocities and relatively low basal stress.

"Surging" glaciers have sufficient flux to reach the fast mode but not sufficient to maintain it, and thus develop a periodically oscillating state between the fast and slow modes with gradual build up and rapid drainage.

Sample results are presented for models of a typical large valley surging glacier and for a very high-speed surging glacier.
\end{abstract}

RÉsumÉ. Un premier modèle simple pour des glaciers sujets a des crues périodiques. On présente un modèle bidimensionnel de l'écoulement d'un glacier qui prend en compte les crues périodiques comme des phénomènes naturels pour une certaine, catégorie de glaciers. Les données comprennent la forme du lit, les profils d'équilibre le long du glacier, les propriétés de l'écoulement de la glace et un facteur de lubrification de la friction. L'effort de friction à la base est déterminé à partir des conditions de l'équilibre général pour l'ensemble du glacier ainsi que la distribution de la lubrification du frottement à partir de la dissipation d'énergie le long du glacier.

Le différence entre l'effort de friction à la base et la contrainte dûe à la pesanteur vers l'aval des glaciers produit des efforts longitudinaux qui déterminent la vitesse de glissement sur le fond. Comme la vitesse intervient également dans la lubrification du frottement, il se développe une rétro-action entre l'effort à la base et la vitesse de glissement.

Pour un facteur de frottement donné, on peut atteindre un stade critique dans lequel la vitesse peut devenir suffisante pour diminuer l'effort de friction à la base de telle sorte que se développe de très hautes vitesses. Le modèle donne alors naissance à une classification en 3 groupes des glaciers avec deux modes d'écoulement.

Les glaciers “ordinaires” n'ont pas un débit suffisant pour un profil donné du lit pour aller au delà du "mode lent" dans lequel l'effort à la base et la vitesse croissent ensemble jusqu'à ce que le glacier atteigne un état d'équilibre.

Les glaciers "rapides" ont un débit assez élevé pour rester constamment dans le "mode rapide" avec de iortes vitesses et des efforts à la base relativement faibles.

Les glaciers "à crues" ont un débit suffisant pour atteindre le mode rapide mais pas assez fort pour le maintenir et manifestent donc un état oscillant périodique entre les modes rapide et lent avec un gonflement progressif suivi d'une débacle rapide.

Zusammenfassung. Ein erstes einfaches Modell für periodisch ausbrechende Gletscher. Es wird ein zweidimensionales Gletscherbewegungsmodell vorgelegt, das periodische Ausbrüche als natürliche Erscheinung für eine bestimmte Klasse von Gletschern einschliesst. Die Ausgangswerte sind die Untergrunds- und Haushaltsprofile längs des Gletschers zusammen mit den Eigenschaften der Eisbewegung und eine Reibungsgleitkoeffizient. Die Spannung am Untergrund wird aus der Bedingung ungefähren Gleichgewichts für den gesamten Gletscher und unter Berücksichtigung der durch den Energieverlust entlang des Gletschers verursachten Reibungswärme ermittelt.

Die Differenz zwischen der Spannung am Untergrund dem Hangabtrieb der Gletscher erzeugt Längsspannungen, die für die Gleitgeschwindigkeit am Untergrund bestimmend sind. Da die Geschwindigkeit aber auch mit der Reibungsgleitung zusammenhängt, entwickelt sich eine Rückkopplung zwischen der Spannung am Untergrund und der Gleitgeschwindigkeit.

Für einen gegebenen Gleitkoeffizienten kann ein kritischer Zustand erreicht werden, bei dem die Geschwindigkeit gross genug wird, um die Spannung am Untergrund zu vermindern, was dann zu sehr hohen Geschwindigkeiten führt. Das Modell liefert somit 3 Gletscherklassen mit 2 Bewegungsarten. 
"Normale" Gletscher haben keinen ausreichenden Massenfluss, der ihnen bei einem gegebenen Untergrundsprofil erlauben würde, sich schneller als in der "langsamen Gangart" zu bewegen, bei der die Spannung am Untergrund und die Geschwindigkeit zusammen anwachsen, so dass der Gletscher einen stationären Zustand erreicht.

Bei "schnellen" Gletschern reicht der Massenfluss aus, um ständig die "schnelle Gangart" mit hohen Geschwindigkeiten und relativ geringer Spannung am Untergrund beizubehalten.

Bei "ausbrechenden" Gletschern reicht der Massenfluss zwar zum Aufbau der "schnellen Gangart", aber nicht zu deren Beibehaltung aus; der Zustand dieser Gletscher wechselt deshalb periodisch zwischen der schnellen und der langsamen Gangart mit allmählichem Aufbau und schnellem Abfluss.

\section{InTRODUCTION}

It has been shown by Campbell and Rasmussen (1969, 1970) that a surge can be induced in a numerical model of a glacier by lowering the basal stress for some time. Physical mechanisms for the lowering of the basal stress of a glacier by the production of melt water have been discussed by Lliboutry (1964, 1969) and Weertman (1962, 1969).

The question arises as to how a water lubrication mechanism for glacier sliding can be incorporated naturally into a numerical model. It is apparent from the high speeds and low basal stresses of the surging and the fast polar glaciers that sliding is the key to the problem.

A numerical model for glaciers in which sliding is small has been developed by Budd and Jenssen (in press) and found to give reasonable approximations to real glaciers over a wide range of sizes. To extend this model to surging glaciers, a realistic mathematical model for sliding must be developed.

A number of theoretical studies of sliding have been presented e.g. Weertman (1957, 1964, 1967), Lliboutry (1958[a], [b], 1968[a], [b]), Nye (1959, 1970), Kamb (1970). These theories have aimed at determining a direct relation between the basal stress and sliding velocity at a certain location of a glacier in terms of the roughness of the bed. Weertman and Lliboutry also deal with multi-valued relations between basal stress and velocity depending on the basal melt water. Shumskiy (1965) argued that a direct relation between the basal stress and the velocity at a point does not in general exist because the glacier as a whole governs what happens at each point. Meier (1968) and Hodge (1972) have shown that the Nisqually Glacier exhibits considerable independence between its basal stress and sliding velocity.

The model to be presented here introduces a simple theory of sliding which requires no direct relation between the basal stress and the sliding velocity at a point, since both are determined from the properties of the whole glacier.

\section{Principles For A SURGing MODEL}

The non-sliding model of Budd and Jenssen (in press) is stable in that if the input, consisting of bedrock, balance, and the properties of the ice, are kept constant then the glacier eventually tends to a steady state from any initial configuration.

For a surging model the following principles are adopted:

(a) With constant input consisting of the bedrock configuration, the accumulationablation balance distribution, and the properties of ice, a steady-state glacier does not result, but instead the glacier builds up slowly then surges rapidly, stagnates then builds up, and repeats the process periodically.

(b) The same laws and ice properties apply to the first order to all temperate glaciers. The final state of a glacier, as surging or non-surging, would then depend on the glacier's bed profile and balance profile.

(c) Surging does not require as a necessary criterion any special features other than sufficient accumulation for the given bedrock profile. Other properties such as special bed smoothnesses, high geothermal flux, etc., are considered as secondary contributors to surging conditions. 
(d) Surging is a large-scale phenomenon which can be adequately represented at least to the first order by a numerical model using discrete values at spacings comparable to the ice thickness. It follows that small-scale bed features are not relevant except in so far as they contribute to bulk averages over larger scales.

The aim of this paper is to outline the theory for the simplest model of glacier flow which includes the class of periodically surging glaciers as a subgroup obeying the same laws.

Numerical results showing the surging sequences that result from such a model are given by Budd and McInnes (in press). These are discussed together with another example of a high-speed surging ice mass in Section 8 . The use of the model for studying particular real surging glaciers will be presented subsequently.

\section{System of equations}

In order to highlight the essential features required for periodically surging, the model here will be kept as simple as possible, concentrating on reproducing the most important properties of real surges first. Greater generality and sophistication can be added later to give closer representation to reality as required.

Hence a two-dimensional model is chosen representing a vertical section along the central flow line of a glacier or any flow line of an ice cap. Parameterization for making the twodimensional profile appropriate for a given valley glacier is discussed by Budd and Jenssen (in press). Additional complications such as special effects of tributaries or valley sides are omitted at this stage. Since very wide ice masses surge, such as Brúarjökull in Iceland (Thorarinsson, 1969), it may be expected that although valley sides are important to a particular glacier, they are not an essential feature of surges generally. The most important features of surging glaciers can be represented in two dimensions as changes of ice thickness and velocity with time along the length of the flow line.

Let $Z$ be the ice thickness, $V$ the average velocity through a column, and $A$ the accumulation-ablation balance at a point distance $x$ along the glacier. Cf. Figure (I).

The variations of the ice thickness with time $t$ are then given by the equation of continuity

$$
\frac{\partial Z}{\partial t}=A-\frac{\partial V Z}{\partial x}
$$

The balance curve $A$ is given as input data together with the bedrock elevation profile $b$ as a function of $x$ along the glacier. Thus if the average velocity $V$ can be expressed as a function of $Z$ and its derivatives at a point then this can be substituted in Equation ( $I$ ) and the problem is reduced to one of kinematic waves. For sliding however no such relation between the velocity and the properties of the glacier at a point can be realistically assumed.

We separate the total average velocity $V$ of a vertical column into a basal sliding component $V_{\mathrm{b}}$ and an average internal deformation component $V_{\mathrm{i}}$ as

$$
V=V_{\mathbf{i}}+V_{\mathbf{b}} \text {. }
$$

For large-scale averages, if the longitudinal strain-rates are small and if a power law for flow applies, the average internal deformation velocity can be satisfactorily expressed in the form

$$
V_{\mathrm{i}}=k \tau_{\mathrm{b}}{ }^{n} Z
$$

where $\tau_{\mathbf{b}}$ is the base stress and $k$ and $n$ are constants.

More general flow laws could be used here but it is shown by Budd and Jenssen (in press) that this formula with $n=2$ and $k=0.15$ bar $^{-2}$ year-1 gives a reasonable approximation to a wide range of glaciers of different sizes. For the case of large longitudinal strain-rates the octahedral stress could also be used. This offers no special difficulty numerically but represents an additional complication at this stage which is not a necessary requirement for the 


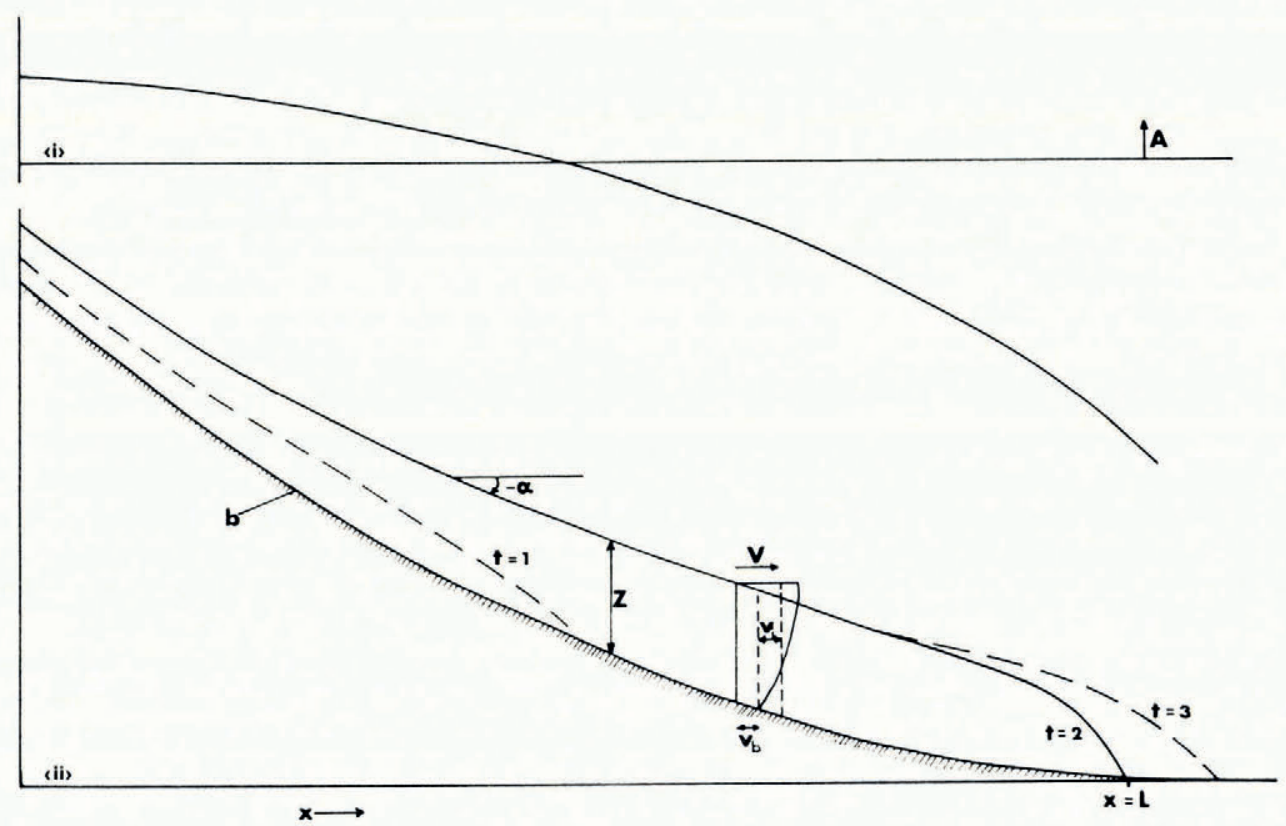

Fig. I. A representation of a two-dimensional model for a glacier is shown. In part (i) a curve is given representing the net accumulation/ablation $A$ as a function of distance $x$ along the glacier. In part (ii) $b$ represents the given bedrock profile, $Z$ the ice thickness, $-\alpha$ the surface slope, $V$ the average total velocity, $V_{\mathrm{i}}$ the average internal deformational velocity, $V_{\mathrm{b}}$ the sliding velocity and $L$ the glacier length at time $t=2$.

surging process. In fact since the base stress drops during the surge when the longitudinal stresses become high, a compensating simplification is also introduced by using for the average internal deformation the expression

$$
V_{\mathrm{i}}=k \tau_{\mathrm{c}}{ }^{n} Z
$$

where $\tau_{\mathrm{c}}$ is the down-slope stress on the centre line given by

$$
\tau_{\mathrm{c}}=\operatorname{s\rho g} \alpha Z
$$

with $\rho$ the ice density, $g$ the gravitational acceleration, $\alpha$ the surface slope, and $s$ a shape factor appropriate for the glacier cross-section, generally to be taken between 0.5 and $\mathrm{I}$.

Since

$$
\alpha=-\frac{\hat{\imath}(Z+b)}{\hat{\imath} x},
$$

and $s, \rho, g$ are constants, the internal velocity given by Equation (4) is determined at each point along the glacier by properties of the glacier at that position. For the basal velocity however we turn to the equation for longitudinal stress equilibrium for scales large compared to the ice thickness and for small surface slopes from Budd (1970):

$$
-2 \frac{\partial \bar{\sigma}_{x_{x}^{\prime}}}{\partial x}=\tau_{\mathrm{c}}-\tau_{\mathrm{b}}
$$

where $\bar{\sigma}_{x}^{\prime}$ is the average longitudinal stress deviator through the column at position $x$.

We define the average generalized viscosity $\eta$ through the column

$$
2 \eta \dot{\epsilon}_{x}=\bar{\sigma}_{x}^{\prime}
$$


where $\dot{\boldsymbol{\epsilon}}_{x}$ is the average longitudinal strain-rate through the column. For the simplest model $\eta$ can be taken as constant. More generally a power or hyperbolic sine flow law could be used. In addition the octahedral stress could be used incorporating the horizontal shear stress as well as the longitudinal stress. However during surges, if the longitudinal strain-rates tend to dominate, it will be sufficient at this stage to neglect the effect of the horizontal shear on the longitudinal strain-rate.

It is emphasized that the flow properties of the ice subjected to longitudinal stresses during a surge are regarded as unknowns here to be determined from the deformation rates occurring during real surges. In fact we wish to study the behaviour of the model to a wide range of constant viscosity values in order to understand fully the role that the ice flow properties play in the mechanics of the surging before moving to a highly non-linear flow relation.

A further simplification is introduced by considering that the changes in the mean longitudinal strain-rate over the large scales we are dealing with are primarily associated with the changes in sliding velocity rather than the internal deformation, i.e.

$$
\dot{\epsilon}_{x}=\frac{\partial V_{\mathbf{b}}}{\partial x} .
$$

Thus Equation (7) can then be written simply as

$$
-4 \frac{\partial}{\partial x}\left(z_{\eta} \frac{\partial V_{\mathrm{b}}}{\partial x}\right)=\tau_{\mathrm{c}}-\tau_{\mathrm{b}} .
$$

At this stage the basal stress $\tau_{\mathrm{b}}$ has still to be determined. Two principles are used to derive it, viz:

(a) The local lowering of basal stress is due to frictional lubrication.

(b) The gross static equilibrium of an ice mass is preserved, i.e. complete break-off and avalanching are not considered here.

If the basal stress is lowered at some point of the glacier, then, by Equation (7), longitudina stresses are introduced up-stream and down-stream. If the glacier is not to accelerate as a whole down the slope, then the basal stress must increase at some other part to prevent this. To preserve the gross equilibrium we require the total basal stress over the whole length $l$. of the glacier to be given by

$$
\int_{0}^{L} \tau_{\mathrm{b}} \mathrm{d} x=\int_{0}^{L} \tau_{\mathrm{c}} \mathrm{d} x .
$$

In order to take account of local lowering of basal stress due to frictional lubrication, we note that the rate of melt-water production is equal to the rate of energy dissipation due to the motion $\tau_{\mathrm{c}} V$. At this stage we do not wish to differentiate between water produced directly at the base due to the sliding $\left(\tau_{\mathbf{b}} V_{\mathbf{b}}\right)$ and that produced from the total energy dissipation $\tau_{\mathbf{c}} V$. This no doubt depends on the internal transport of water in the ice mass, which still requires further investigation. For the numerical model calculations it does not matter greatly which expression is used so we choose the total dissipation $\tau_{\mathrm{c}} V$ for simplicity.

Thus we seek a formula which gives a local reduction in $\tau_{\mathrm{b}}$ with increasing $\tau_{\mathrm{c}} V$. Many such formulae of various complexity can be developed, but at this stage we look for the simplest. Hence we define the local lubrication-lowered stress as

$$
\tau_{\mathrm{c}}^{\star}=\frac{\tau_{\mathrm{c}}}{\mathrm{I}+\phi \tau_{\mathrm{c}} V}
$$

where $\phi$ is an adjustable parameter called the friction lubrication factor. Here we take $\phi$ as a constant, but for increased complexity it could be made variable and also include more complex functions of $\tau_{\mathrm{c}} V$. 
To preserve gross equilibrium we define average stresses over the glacier by

$$
\bar{\tau}_{\mathrm{c}}=\frac{\mathrm{I}}{L} \int_{\mathrm{o}}^{L} \tau_{\mathrm{c}} \mathrm{d} x, \quad \bar{\tau}_{\mathrm{c}}{ }^{\star}=\frac{\mathrm{I}}{L} \int_{0}^{L} \tau_{\mathrm{c}}{ }^{\star} \mathrm{d} x .
$$

The basal stress $\tau_{\mathrm{b}}$ is then taken as

$$
\tau_{\mathrm{b}}=\bar{\tau}_{\mathrm{c}}+\left(\tau_{\mathrm{c}}{ }^{\star}-\bar{\tau}_{\mathrm{c}}{ }^{\star}\right) .
$$

This equation has the property that gross equilibrium is preserved, i.e.

$$
\bar{\tau}_{\mathrm{b}}=\bar{\tau}_{\mathrm{c}}
$$

and that locally the stress difference $\left(\tau_{\mathrm{c}}-\tau_{\mathrm{b}}\right)$ is greatest where $\tau_{\mathrm{c}} V$ is greatest.

Having determined the basal stress distribution, the basal velocity can be obtained by integration of Equation (10), provided we can specify the boundary conditions.

Since the boundary conditions are not well known the following will be taken as working assumptions.

(i) The longitudinal strain-rate due to sliding tends to zero at the terminus as $Z$ tends to zero, i.e.

$$
\frac{\partial V_{\mathrm{b}}}{\partial x}=0 \quad \text { at } x=L .
$$

This says that as the ice thickness becomes small near the front, any sliding that occurs tends to be like a block at the end point.

(ii) The horizontal velocity at the start is taken as zero, i.e.

$$
V=0 \quad \text { at } x=0 .
$$

For ice masses starting at ice divides this is certainly true, but for glaciers starting on steep slopes some modification may be necessary.

Hence we obtain for the longitudinal strain-rate due to sliding

$$
\frac{\partial V_{\mathrm{b}}}{\partial x}=\frac{\mathrm{I}}{4 Z_{\eta}} \int_{i .}^{x}\left(\tau_{\mathrm{c}}-\tau_{\mathrm{b}}\right) \mathrm{d} x .
$$

The sliding velocity is then given by

$$
V_{\mathrm{b}}=\int_{0}^{x} \frac{\partial V_{\mathrm{b}}}{\partial x} \mathrm{~d} x
$$

Thus, having determined the sliding velocity, the total velocity is given by Equations (2) and (4). This is then used in the equation for basal stress and the system can be cycled for convergence. For a time-varying numerical model, the velocity is fed into the continuity equation ( $\mathrm{I}$ ) and the system is cycled by time-stepping. 'The time step must be chosen sufficiently small so that the glacier dynamics can keep up with the changes in ice thickness, or otherwise more frequent cycling for the velocities is required, cf. Table I.

\section{Operation of the model}

To begin with, the model can be run with the lubrication factor $\phi$ zero, then the sliding is eliminated and the glacier grows to steady state. For steady state

$$
\frac{\partial z}{\partial t}=o
$$


Table I. Calculation routine

Set $b, A$ as functions of $x$.

Set $k, n, \eta, \phi, s, \rho, g$ as constants.

Specify grid spacing $\delta x$ and time step $\delta t$.

Any initial thickness profile $Z^{\prime}$ may be specified.

Otherwise $Z=0, V_{\mathrm{b}}=0$, at $t=0$.

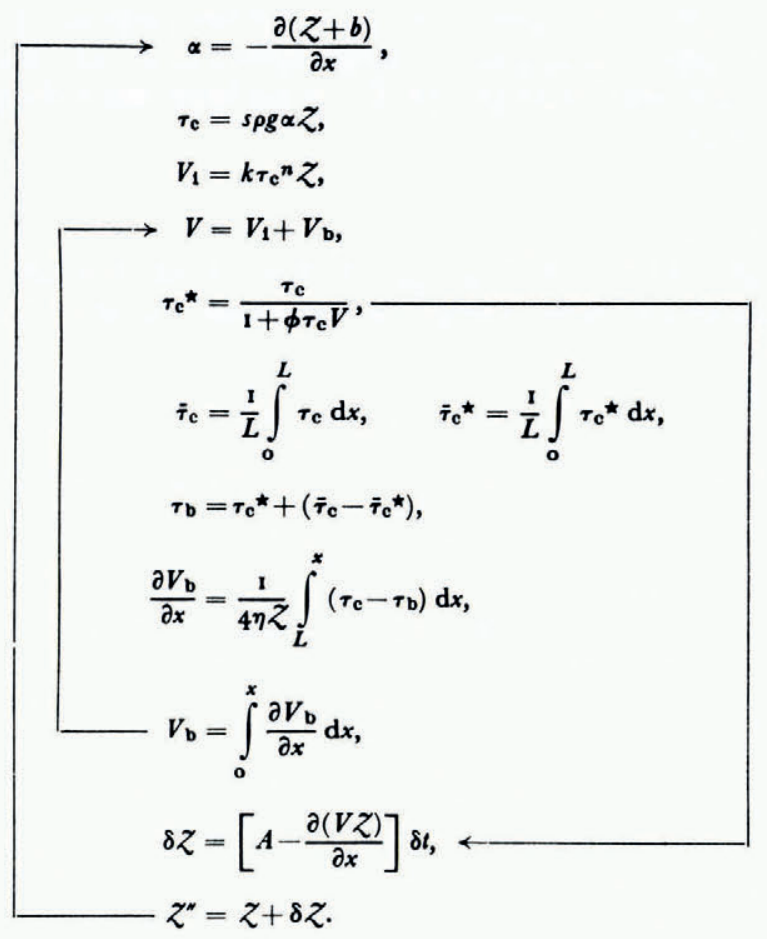

and the glacier reaches a length $L$ determined by

$$
\int_{0}^{L} A \mathrm{~d} x=0 .
$$

The maximum flux $\Phi_{\mathrm{m}}$ occurs at the firn line, say $x=f$, and is given by

$$
\Phi_{\mathrm{m}}=V_{\mathrm{m}} Z_{\mathrm{m}}=\int_{0}^{f} A \mathrm{~d} x=-\int_{f}^{L} A \mathrm{~d} x=\frac{1}{2} \int_{0}^{L}|A| \mathrm{d} x .
$$

For sufficiently small non-zero $\phi, \tau_{\mathrm{b}}$ is slightly less than $\tau_{\mathrm{c}}$, so a small amount of sliding occurs, depending on the value of the parameter $\eta$. Provided $\eta$ is not too small, a new steady state is reached similar to that for zero $\phi$ except that, for the position of maximum flux, $V$ is slightly greater and $Z$ is slightly less than for the case of zero $\phi$. As $\phi$ is increased the sliding velocity increases and, provided $\eta$ is sufficiently small, a critical stage is reached for which $\phi \tau_{\mathrm{c}} V$ is large enough to lower the base stress appreciably which causes the sliding velocity to increase and through the feed-back of Equations $\left(5^{\star}\right)$ to $\left(9^{\star}\right)$ gives rise to a high velocity zone near the region of the glacier where $\tau_{\mathrm{c}} V$ is a maximum. This fast zone with longitudinal 
extension up-stream and compression down-stream moves as a dynamic (non-kinematic) flux wave and spreads out down the glacier. The surge finishes as the fast velocity zone spreads through the terminus carrying mass with it and causing the rapid advance. After the surge, the reduced slope causes a reduction in the stress and the velocity which through Equations $\left(3^{\star}\right)$ to $\left(9^{\star}\right)$ reduces the sliding so that the motion reverts to the former slow mode. The advanced front then gradually becomes reduced by ablation while the accumulation zone thickens until $\tau_{\mathrm{c}} V$ is sufficiently large once again and the surge is repeated.

The speed of the surge depends on the values of $\eta$ and $\phi$, but also on the length of the glacier, the thickness, the bedrock slope, etc. If $\eta$ is too large, the sliding is also reduced below the critical value to surge.

\section{Critical values}

In order to obtain an idea of the appropriate range of values to use for $\phi$, we examine the function $\tau_{\mathrm{c}}{ }^{\star}$. For the case of zero sliding, if we substitute $V$ from Equation (4) into (12) we obtain

$$
\tau_{\mathrm{c}}^{\star}=\frac{\tau_{\mathrm{c}}}{\mathrm{I}+\phi k \tau_{\mathrm{c}}{ }^{3} Z} .
$$

This function of $\tau_{\mathrm{c}}$ for constant $\phi, k$ and $Z$ has a maximum when

$$
\tau_{\mathrm{c}}=(2 \phi k Z)^{-1} \text {. }
$$

The studies of ordinary and fast glaciers for numerical modelling by Budd and Jenssen (in press) suggest that a maximum $\tau_{\mathrm{c}}$ of about 2 bars is appropriate. Similarly with $Z \approx 500 \mathrm{~m}$ the maximum deformational velocity would be $V \approx 300 \mathrm{~m} / \mathrm{year}$. Thus to obtain a maximum of $\tau_{\mathrm{c}}$ for $\tau_{\mathrm{b}} \approx 2$ bars and $V \approx 300 \mathrm{~m} /$ year we may expect a maximum for $\phi$ of

$$
\begin{aligned}
\phi & \approx\left(\tau_{\mathrm{b}} V\right)^{-1} \\
& \approx \mathrm{I} .7 \times 1 \mathrm{IO}^{-3} \mathrm{bar}^{-1} \mathrm{~m}^{-1} \text { year }^{-1} .
\end{aligned}
$$

Since the sliding velocity increases the value of $\tau_{\mathrm{c}} V, \tau_{\mathrm{c}}{ }^{\star}$ drops even lower, but Equation (25) gives a starting point for the program and we can examine the range $\phi \approx 1 \mathrm{IO}^{-5}-\mathrm{IO}^{-2}$.

The maximum value of $\tau_{\mathrm{c}} V$ may be expected to develop near the firn line for which from Equations (5) and (22)

$$
\tau_{\mathrm{c}} V=\operatorname{s\rho g} \alpha \int_{0}^{f} A \mathrm{~d} x=\operatorname{s\rho g} \alpha \Phi .
$$

Since this is independent of ice thickness, it follows that, for this model, glaciers of various sizes may surge, provided the input, $\int_{0}^{f} A \mathrm{~d} x$, is sufficiently large. Glaciers of steeper slopes would be expected to reach the critical stage earlier, i.e. for smaller thicknesses. To apply this in practice however, it should be noted that the width needs to be parameterized.

To simulate the fast polar glaciers it is merely necessary to increase the accumulation zone flux to sufficiently high values to maintain the glacier flow in the fast mode, i.e. high velocities with relatively low base stresses.

Thus with this model a natural classification scheme for glaciers presents itself as follows:

(i) "Ordinary glaciers" are those whose flux for their bed profile is low enough for the glacier to remain in the "slow mode", i.e. with the base stress increasing with the velocity.

(ii) "Fast glaciers" are those whose flux is sufficiently high to maintain the glacier in steady state in the "fast mode", i.e. with a high velocity and a lowered base stress. 
(iii) "Surging glaciers" are those whose flux is sufficiently high for the glacier to reach the fast mode before reaching steady state but not sufficient to maintain it in the fast mode. Thus these glaciers build up slowly until they reach the fast mode, drain out rapidly in a surge then slowly build up again-periodically oscillating from one mode to the other.

In times of changing climate it is possible for surging or non-surging glaciers to pass from one type to the other by sufficiently large changes in the balance.

As an estimate of the order of magnitude of the critical flux from Equation (26), the studies of real glaciers for numerical modelling by Budd and Jenssen (in press) and Budd and Allison (in press) suggest that a value of $s \alpha V Z \approx 500 \mathrm{~m}^{2}$ year $^{-1}$ may separate the surging from the ordinary glaciers.

\section{Special characteristics of SURging glaciers}

In order to test the hypothesis of a critical $\tau_{b} V$, we note from Equation (26) that for the critical zone separating surging from non-surging glaciers the surface slope would be inversely proportional to the flux rate $\Phi$ times the shape factor $s$. To calculate the shape factor we really need the ice thickness, which is not available for most surging glaciers. However if we select surging glaciers over a wide range of surface slopes and flux rates then the precise value of the shape factor, which varies generally between 0.5 and $I$, is not so important.

TAble II. Approximate surface slopes and fluX rates for some surging glaciers

Only the main trunks of the glaciers are included here. In some cases tributaries could also be considered.

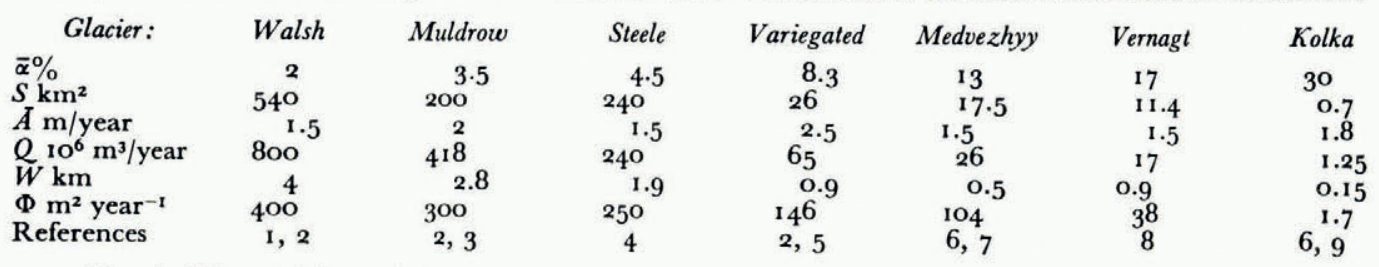

r. Post (1966), 2. Meier and Post (1969), 3. Post (196o), 4. Stanley (1969), 5. Post (r969), 6. Dolgushin and Osipova (1971), 7. Dolgushin and Osipova (in press), 8. Hoinkes (1969), 9. Personal communication from Dr V. M. Kotlyakov.

Hence in Table II a list of glaciers is shown with estimates of the following quantities:

Mean surface slope $\bar{\alpha}$,

Area of accumulation zone $S$,

Average net accumulation rate above the firn line $A$,

Total mass flux at the firn line $Q=\bar{A} S$,

Width of the glacier near the firn line $W$,

Flux rate $\Phi=V_{\mathrm{c}} Z$ where $V_{\mathrm{c}}$ is the centre-line surface velocity and $Z$ is the centre-line thickness near the firn line.

The flux rate $\Phi$ is estimated from the total mass flux $Q$ by the relation

$$
Q=\bar{W} \bar{\nabla} Z
$$

where $\bar{W}$ is the mean width of the section and $\bar{V}$ is the mean velocity over the section.

Two further shape factors are introduced following Budd and Jenssen (in press)

$$
s_{2}=\frac{\bar{V}}{V}
$$




$$
s_{3}=\frac{\bar{W}}{W} .
$$

The flux rate per unit width"at the centre line is then given by

$$
\Phi=\frac{Q}{s_{2} s_{3} W} .
$$

For the above calculations the product $s_{2} s_{3}$ has been taken as $\approx 0.5$.

From the values of $\Phi$ and $\bar{\alpha}$ in Table II it is apparent that the inverse proportionality of Equation (26) does tend to apply.

Using the empirical graph of glacier surface slopes versus velocity as discussed by Budd and Jenssen (in press) and Budd and Allison (in press) these flux rates and surface slopes for surging glaciers can be compared to corresponding values for the ordinary glaciers and the fast polar glaciers, cf. e.g. Carbonnell and Bauer (1968).

The heavy dashed line in Figure 2 represents a curve of approximately constant $\alpha \Phi$ which, for constant shape factor, would also be a constant $\tau_{\mathrm{b}} V$ curve. This curve tends to separate the bulk of ordinary glaciers from the fast polar glaciers. The plotted points for the surging glaciers tend to fall on the fast side of this curve. Thus for steady state these surging glaciers would tend to have high $\tau_{\mathrm{b}} V$ values if they were to flow in the ordinary mode.

In spite of the scarcity of data for surging glaciers this empirical analysis suggests that the frictional lubrication basis for a surging model may at least match reality in the first approximation.

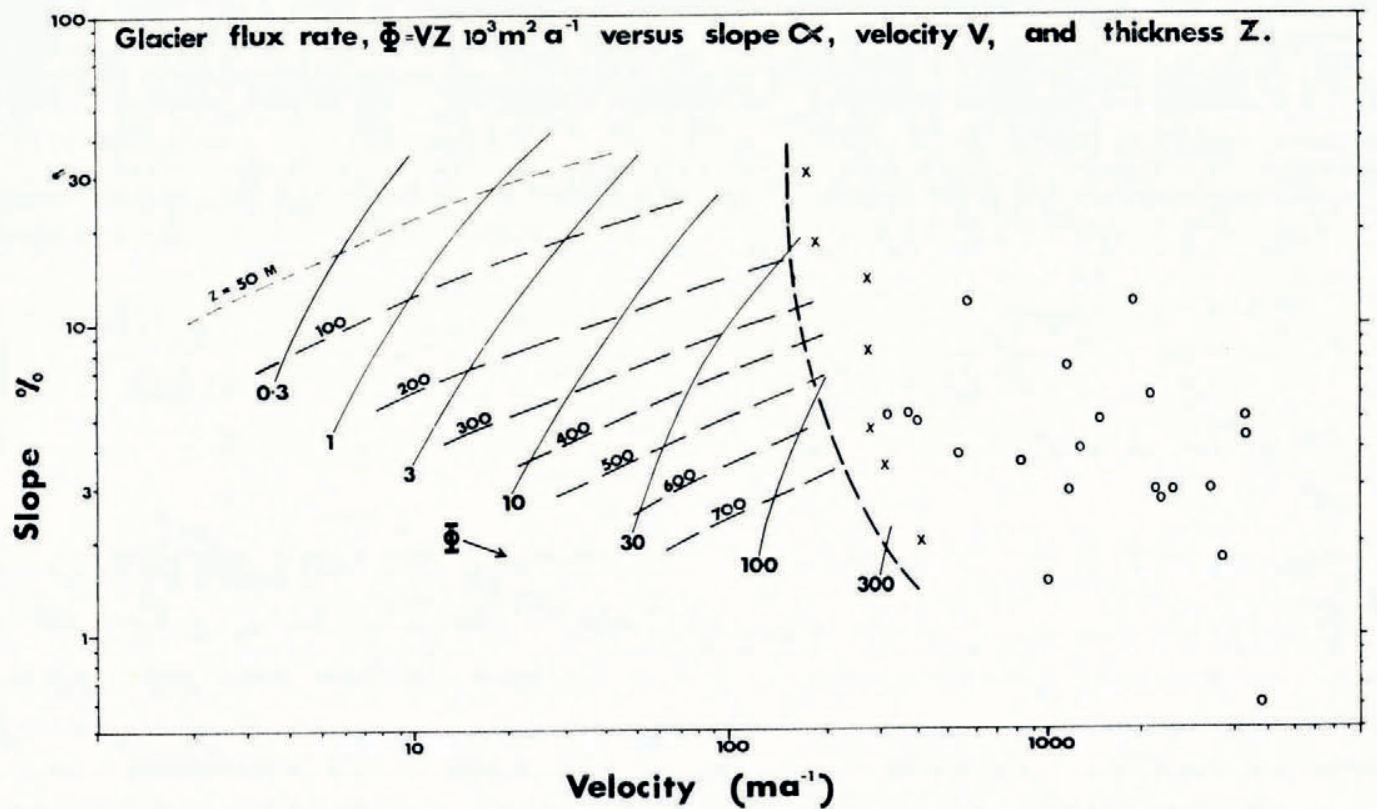

Fig. 2. From a compilation of measurements on ordinary glaciers, the mean centre-line ice thicknesses $Z$ are shown as a function of surface slope $\alpha$ and centre-line surface velocity $V$. From these curves the centre-line flux rate $\Phi=V Z$ is obtained as shown by the full curves. Individual points for some fast polar glaciers are shown by the circles in the high-velocity region. The crosses are obtained from the fluxes and slopes of some surging glaciers. These tend to be generally between the values for the ordinary glaciers and the fast polar glaciers. The heavy broken line represents a constant $\alpha \Phi$ curve which suggests this may define a transition zone between the ordinary and fast glaciers. 


\section{Matching ReAl SURges}

In the present model the magnitude of the surge depends primarily on the amount by which the flux, for the given slope and cross-section, is greater than the critical value. Thus the size of the surge is altered by changes in the climate through the balance curve.

Similarly the period between surges is altered by changes in the balance associated with climate changes. The length of the period depends on the time taken for the glacier to build up to the critical size.

The duration of a surge for the model is dependent on the speed of the surge and the length of the glacier. Thus the values of $\eta$ and $\phi$ in the model control the duration of the surge through their control of the surge speed. The durations of real surges have considerable variation, e.g. Kutiah $12 \mathrm{~km}$ in 2 months (Desio, r954), Brúarjökull $8 \mathrm{~km}$ in 4 months (Thorarinsson, I969), Muldrow $6.6 \mathrm{~km}$ in about 2 years (Post, I960), Walsh $11.5 \mathrm{~km}$ in about 6 years (Post, I966; Meier and Post, I969).

Although the duration of a surge in the model of a particular glacier can be controlled by the $\eta$ and $\phi$ values, it may not be possible with the present model to match the wide range of durations given above with the same values of $\eta$ and $\phi$ for all glaciers. Two obvious extensions can be made to the model which will effect the surge duration. First a non-linear longitudinal stress-strain-rate relation would simulate a wide range of effective viscosities for surging, in that those which develop large longitudinal stresses would have lower viscosity and surge faster than those with smaller longitudinal stresses. Secondly the effect of the valley sides, especially on glaciers wide relative to their depth, can be important to the shear-stress distribution around the boundary of the cross-section. A simple partitioning scheme for separating vertical and horizontal shear stresses as discussed by Budd and Radok (1971, p. 32) could be useful for controlling the duration of the surge. This problem will be treated further in the context of using the model in matching particular real surges.

\section{SAmple Results}

There are a large number of different types of surging ice masses which could be examined by the present model. Just two examples are presented here to show the scope of the model in representing two particularly interesting types of different surging ice mass. The first is an example of a typical large valley glacier (such as Walsh, Muldrow or Steele) which moves at the rate of several $\mathrm{km} /$ year over a number of years. The second is an example of a high-speed surging ice mass (such as Brúarjökull) which moves an order of magnitude faster at the rate of several tens of $\mathrm{km} /$ year (over $100 \mathrm{~m} / \mathrm{d}$ ) for a period of a few months.

The same model is used in each case with just different values of the input, viz. the bedrock profile and balance profile (or two-dimensional parameterized influx profile) characteristic of the particular ice mass. In each case the model is examined for a wide range of the parameters viscosity $\eta$ and lubrication factor $\phi$.

For a particular run with the given input, the parameters $\eta$ and $\phi$ are set, and the ice is grown from zero thickness and run for a pericd of from 700 to I ooo years, by which time the "final state" of the ice mass is apparent.

The input bedrock and balance (or influx) curves are shown for the two cases in Figures 3 and 5 . In each case for small values of $\phi$ and reasonable $\eta$ the ice masses grow up to a steady state, as shown, e.g. in Figure $3 \mathrm{~b}$. As the lubrication factor $\phi$ is increased, the maximum value of the sliding velccity increases. For any value of $\eta$, not too large, a certain stage is reached for which the ice mass surges and continues to do so periodically until a final uniformly repeating surging state is reached as shown in Figures 4 and 6.

For a given bedrock and balance profile the critical value of the lubrication factor for surging depends on the value of the viscosity $\eta$. The distribution of sliding velocities over the 


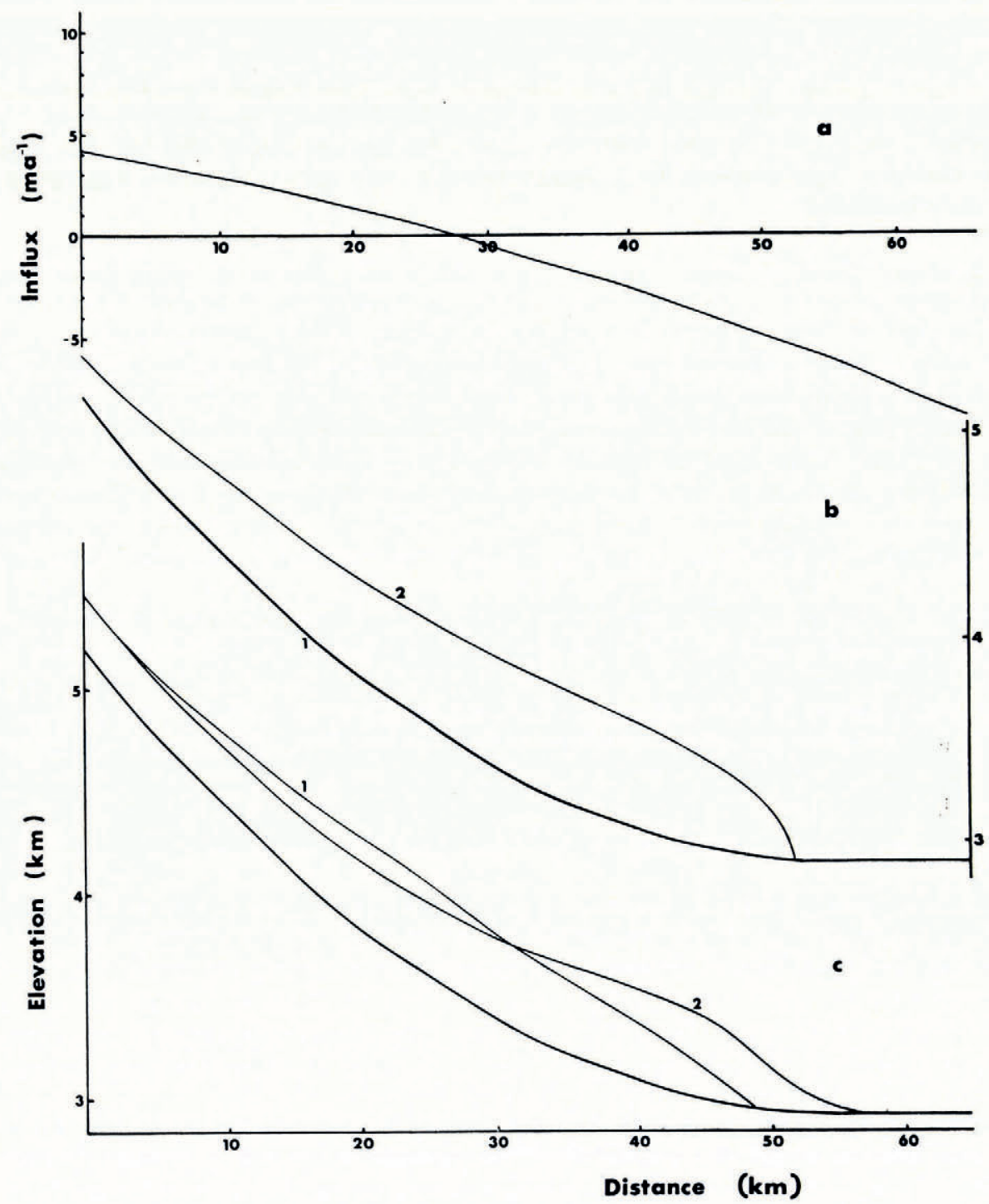

Fig. 3. The input data for the model consists of the net accumulation/ablation balance curve (a) as function of distance along the glacier, and the glacier bedrock profile $(b$, lower curve). For the non-surging case the glacier builds up to a limiting steadystate profile (b, upper curve). For the surging case the glacier develops periodically a steep profile $(c, r)$ which rapidly transforms to an extended flatter profile $(c, 2)$ during the surge.

domain of lubrication factor and viscosity is shown in Figure 7. Here the surge-non-surge boundary is shown by the broken line which lies generally between the $10^{2}$ and $10^{3} . \mathrm{m} /$ year velocity isopleths. For low viscosities this boundary is very sharp but for high viscosities it broadens until the viscosity becomes too high for surging altogether. A variation of the input data for the balance or bedrock profiles results in a general shift in the sliding velocities with respect to the axes, but the general pattern is preserved. The data for Figure 7 come from several hundred different runs growing the ice mass from zero to a final state using the same 


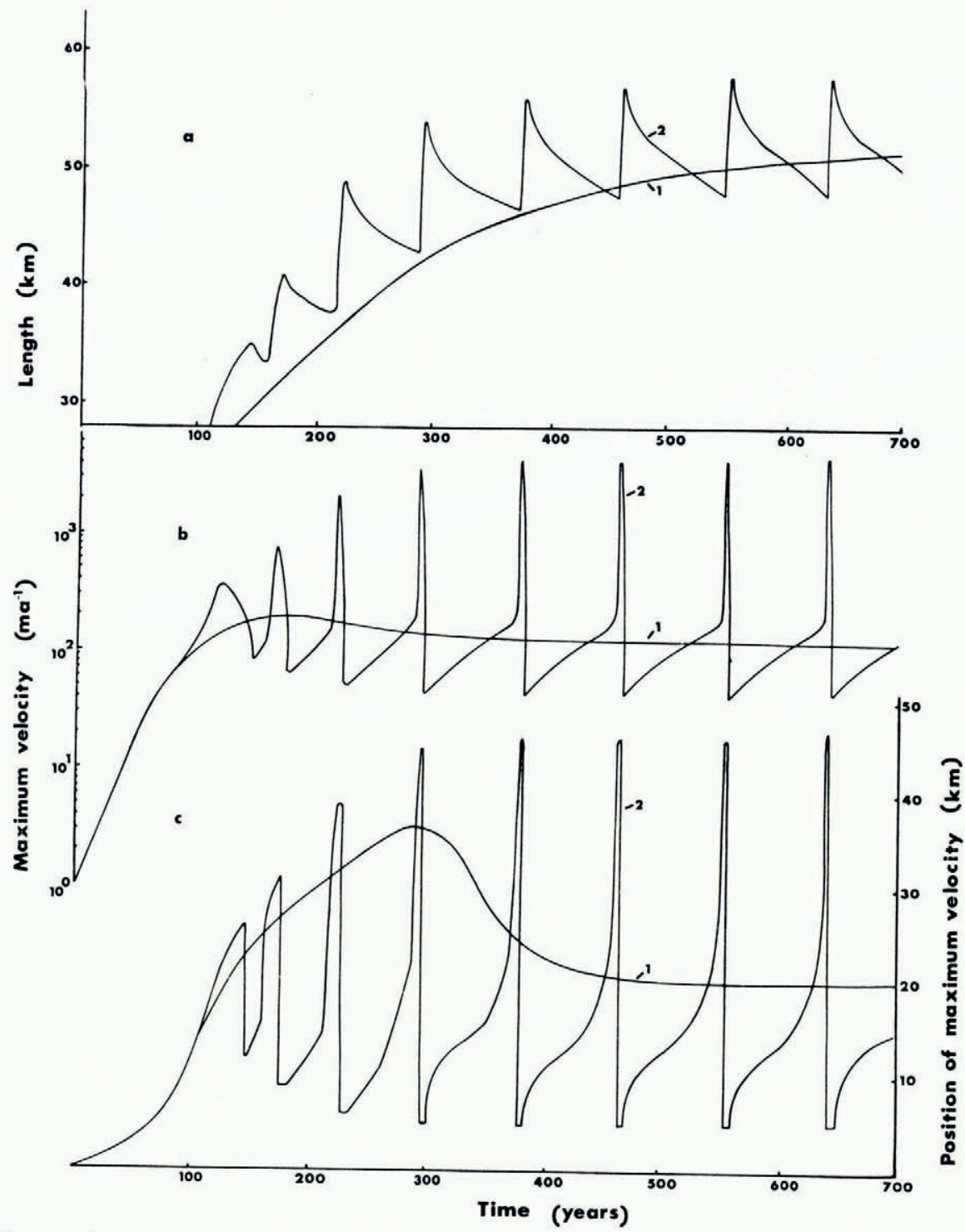

Fig. 4. The growth of the model towards steady state for an ordinary glacier ( $I)$ and a surging type glacier (2) is illustrated by the variation with time of the glacier's length $(a)$, the maximum velocity $(b)$, and the position of the maximum velocity (c). The ordinary glacier gradually tends towards a constant steady state whereas the surging glacier develops a periodically oscillating state characterized by a long period of slow build-up with retreat followed by a rapid advance at high speed. In the course of a surge cycle the position of maximum velocity travels down the glacier as a flux wave with increasing speed from the accumulation zone to the region of the terminus.

input but varying the values of $\phi$ and $\eta$. The output is very large and similar diagrams can be constructed for other features of the ice mass such as maximum thickness, surge duration, surge period, length of surge advance, etc., to show how these vary over the domain of $\phi$ and $\eta$.

In this way it is possible to select some features of a measured glacier surge which can be matched by the model using certain values of $\eta$ and $\phi$. 

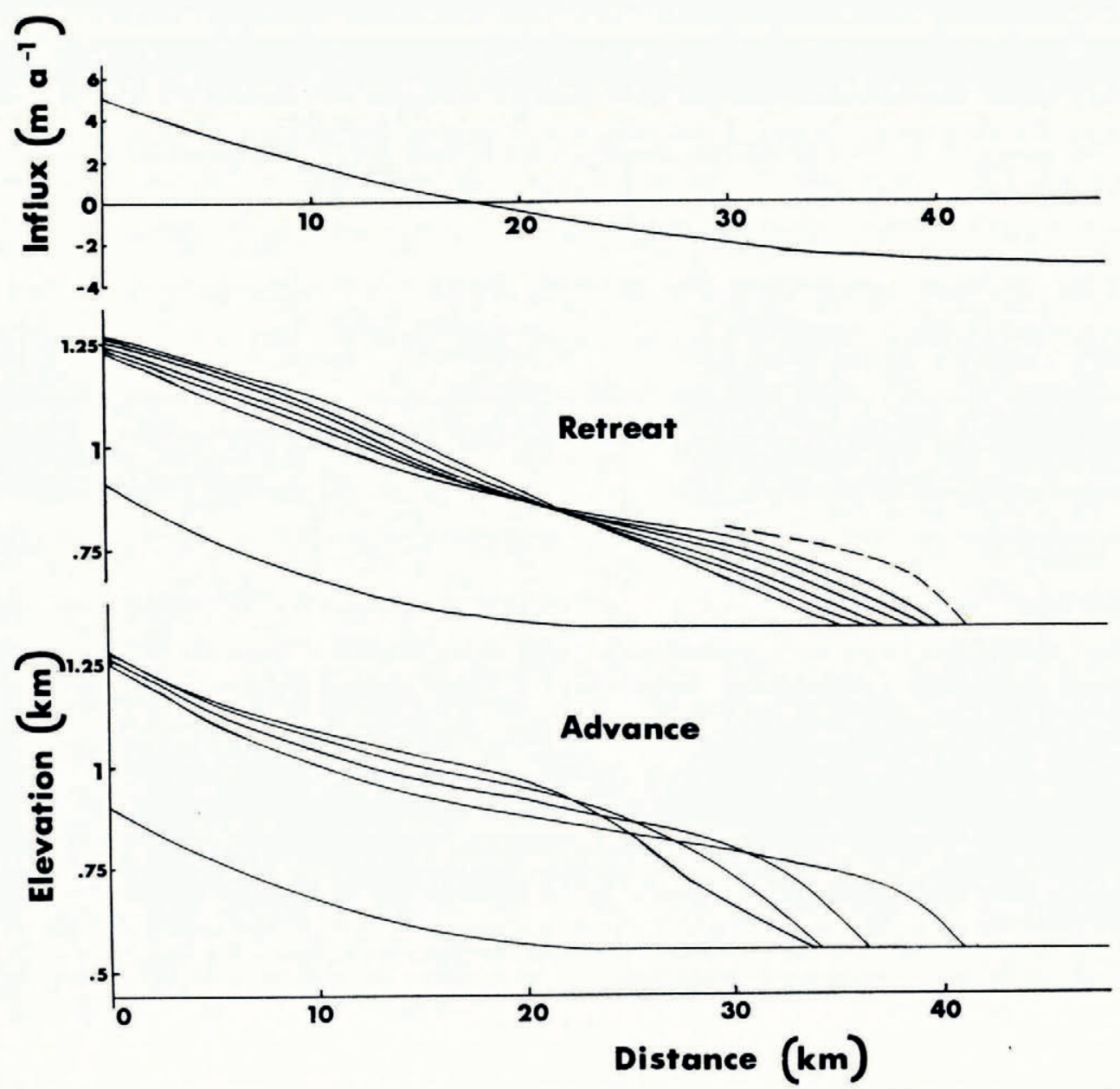

Fig. 5. For an idealized smooth analogue to a flow line of the Brúarjökull, the influx curve shown in (a) represents an accumulation/ ablation balance curve modified to take some account of the varying width. A corresponding smoothed bedrock profile is shown in $(b)$ and $(c)$. The resultant surface profile of the ice mass after about 700 years is shown for a retreat phase at 10 year intervals in $(b)$ and for a rapid advance phase in $(c)$ at intervals of $0.1,0.1,0.15$ years from the start of the advance.

For temperate glaciers the value of $\eta$ depends on the stress. Even at a stress of one bar, field and laboratory values seem to be scattered over an order of magnitude. Thus it is necessary to consider a wide range of $\eta$ values. Typical values should lie between $10^{-1}$ and Io bar year. For cold ice masses the viscosity could be typically one to two orders of magnitude higher and Figure 7 shows that under similar conditions the cold ice mass would surge with lower velocities than the corresponding temperate ones.

For the valley glacier example of Figure 3, a smooth bedrock and balance profile was selected similar to the measured values on Lednik Fedchenko but somewhat lower as one would expect without tributaries. An increase in $\phi$ to $10^{-4} \mathrm{bar}^{-1} \mathrm{~m}^{-1}$ year-1 results in a surging glacier with maximum speed of over $4 \mathrm{~km}$ per year, advance duration 3 years, surge period 88 years, and advance distance of $10 \mathrm{~km}$, as illustrated in Figure 4. These surge features are not unlike those measured, e.g. on Walsh or Steele Glaciers. The change in the thickness profile is also of a similar magnitude as shown in Figure 3. 

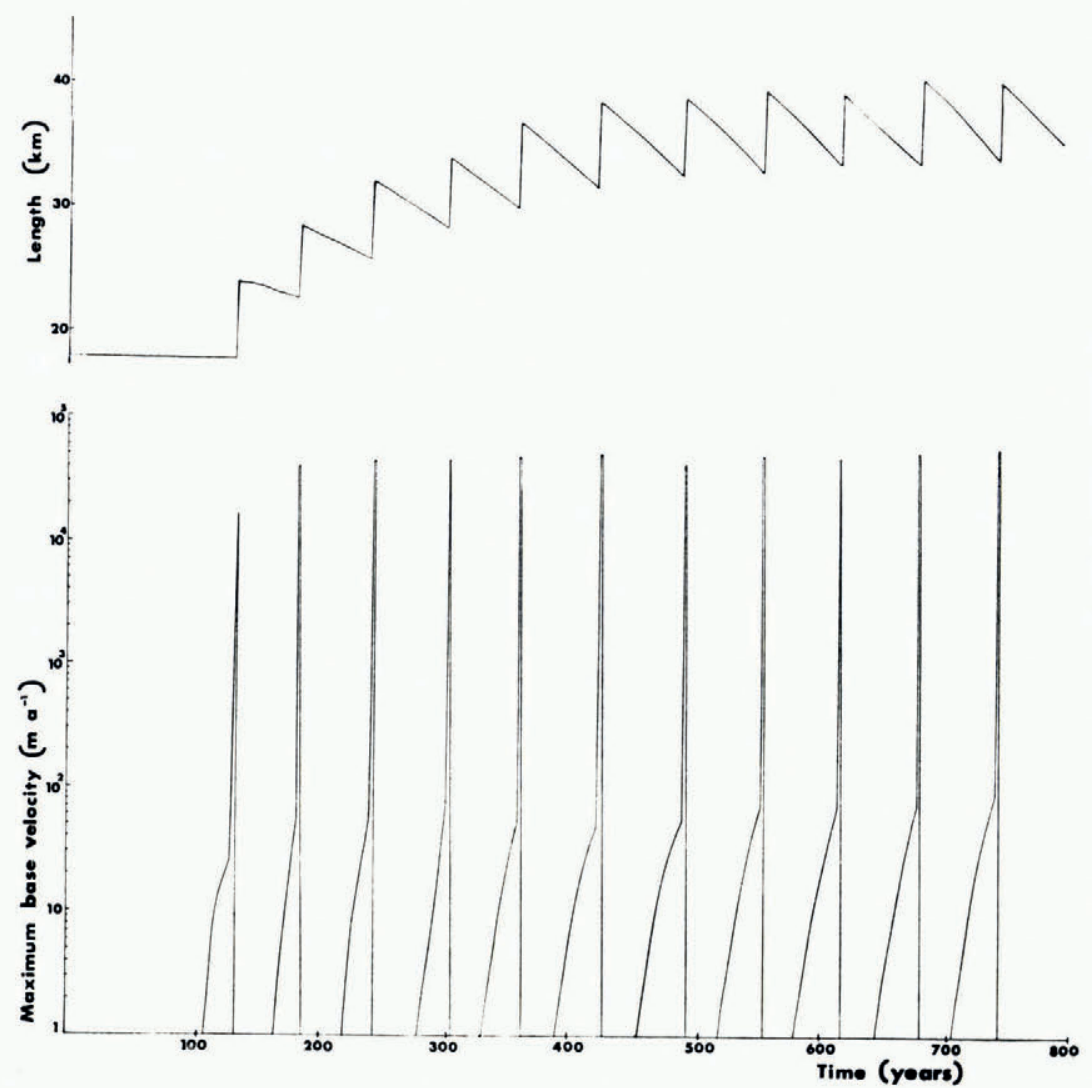

Fig. 6. The change in the length of the idealized Briarjökull model is shown in (a) for the glacier grown from zero thickness with influx and bedrock profiles given in Figure 5. After about 700 years the ice mass exhibits regular periodic surging. In (b) the magnitude of the maximum sliding velocity is shown on a logarithmic scale. The sliding velocity is very low for most of the period, gradually increasing to about $50 \mathrm{~m} /$ year after which the surge sets in and the velocity reaches $50 \mathrm{~km} /$ year for a few months before dropping back to nearly zero to repeat the cycle.

The progress of the surge is characterized by the movement of a broad wave down the glacier as shown by the position of the maximum velocity shown in Figure 4c, 2. A similar wave can be seen as a travelling thickness perturbation for the second example in Figure 5 . This wave starts building up in the accumulation zone right after the surge and moves down the glacier with increasing speed towards the terminus. The rapid advance occurs as the wave passes through the terminus.

With the same values of $\eta$ and $\phi$, the surging glacier reverts to a non-surging glacier by a reduction of the balance curve. Similarly the non-surging glacier can be changed to a surging one by an increase in the balance curve.

Variations of the bedrock slope also shift the pattern of sliding velocities and the surgenon-surge boundary over the domain of $\eta$ and $\phi$.

Finally, even with this first simple model it seems to be possible to match measured glacier surges in many respects by an appropriate selection of the values of $\eta$ and $\phi$.

For the very high-velocity example, a smooth bedrock profile similar to a flow line for Brúarjökull is used as shown in Figure 5. The influx curve is a modified balance curve chosen to include some effects of the varying width of the ice mass along the flow line, although no 


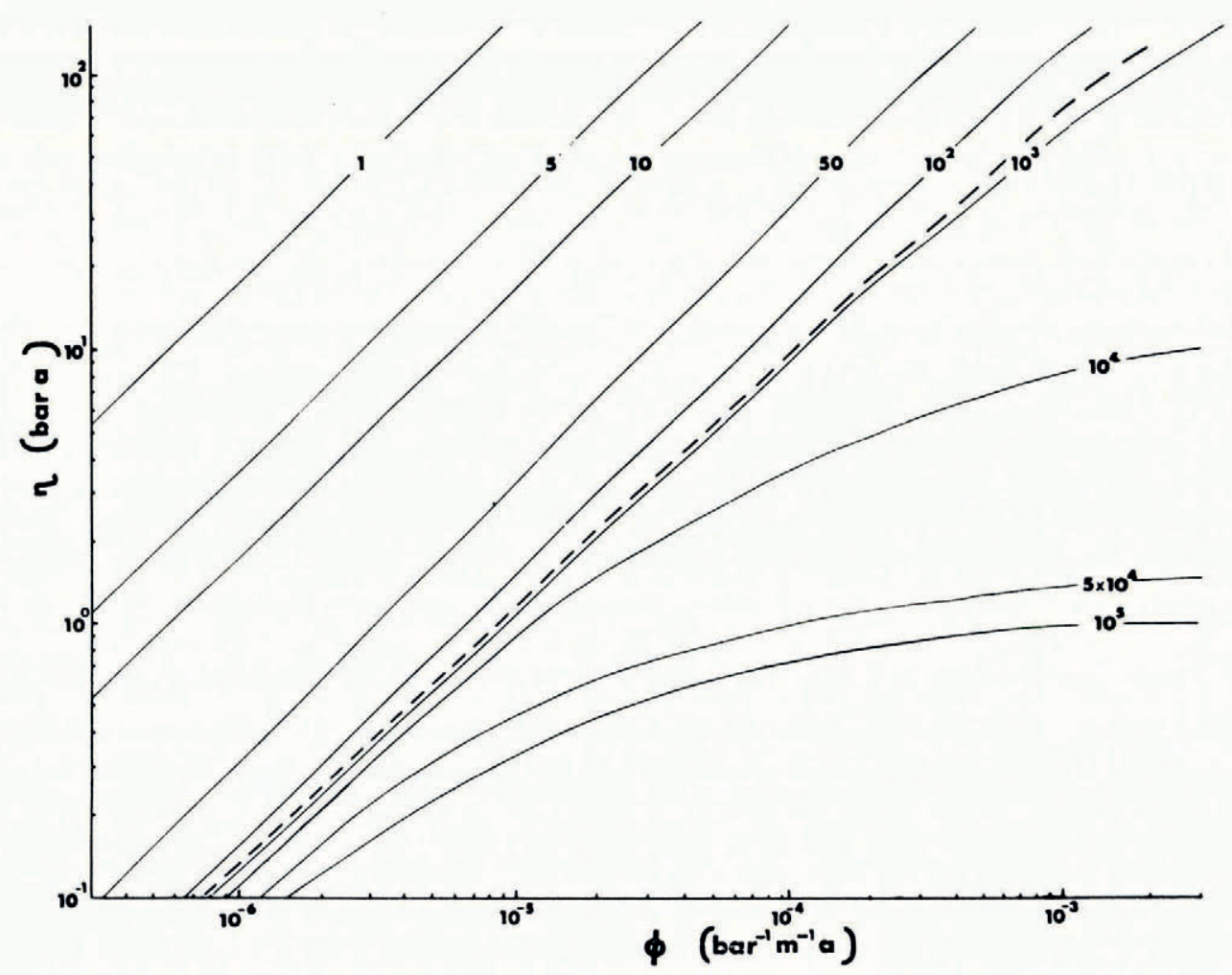

Fig. 7. The variation in the maximum sliding speed of the idealized Bruarjökull model of Figure 5, over the domain of different values for the viscosity $\eta$ and lubrication factor $\phi$, shown in $\mathrm{m} / \mathrm{year}$. The dashed line shows the division between the steadystate, to the left, and the surging results, to the right. The maximum speed for the steady-state results usually occurs early in the development so that final sliding speeds much greater than $100 \mathrm{~m} /$ year tend to develop surging.

attempt to give an exact match has been made at this stage. The resultant sliding velocity distribution over the domain of $\phi$ and $\eta$ is that shown in Figure 7 . For values to the left of the dashed line a steady state is reached while those to the right result in regular periodic surging as shown by the velocity and length changes in Figure 6 . The steady-state profiles of ice thickness tend to be generally thicker than the measured profile, whereas the surging profiles of ice thickness as shown in Figure 5 are somewhat thinner. This is a result of higher average velocities for surging ice masses. It is expected that closer matching can be achieved by using a more representative influx curve.

Nevertheless the example given has many features similar to those associated with the measured surges of Brúarjökull. If a realistic value of $\eta$ of $\mathrm{I}$ bar year is chosen, then a value of $\phi=\mathrm{I} .7 \times \mathrm{1O}^{-4}$ gives a maximum surge speed of $5 \mathrm{I} \mathrm{km} /$ year and a surge duration of 0.3 year. These results are illustrated in Figures 5 and 6 . The observed features of the 1963 surge included an average speed of $5 \mathrm{~m} / \mathrm{h}(44 \mathrm{~km} /$ year $)$ over a duration of less than 3 months (Thorarinsson, 1969). The advance derived from the model is $7 \mathrm{~km}$, a little less than that measured. The change in thickness also seems compatible with the measured changes. The period of the surging is about 64 years compared to 73 years between 1890 and 1963 . It is expected that the period increases slightly with the ice thickness here.

The changes in the thickness profile for ro year intervals through a retreat phase is shown in Figure $5^{\mathrm{b}}$. The dashed line shows the most advanced position just after the surge identical 
to that of Figure $5 \mathrm{c}$, which shows the changes in the profiles during an advance for the times $0,0.1,0.2,0.35$ years from the commencement of the advance. These illustrate the rapid movement of the thickness wave to the terminus and beyond within just a few months.

The pattern of thickness changes with time also have a remarkable resemblance in general form to the few data available from measured glacier surges, including the bulged advancing front and the straightening retreating profile. Figure 6 shows the change in length and sliding velocity with time. The logarithmic scale on the velocities illustrates the dramatic changes during and after the surge. The gradual approach to regular periodic surging over 700 years is clearly apparent.

Finally it also seems possible on this simple model to match these high-speed surging ice masses by appropriate values of the parameters. The difference in parameters from one ice mass to another will depend on a number of factors such as the effect of valley sides, the general bed roughness, and the geothermal flux. For zones with unusually large geothermal flux rates (say $q$ in mechanical units), it may be appropriate to include this as an extra parameter contributing to the melt production rate by writing

$$
\tau_{\mathrm{c}}^{\star}=\frac{\tau_{\mathrm{c}}}{\mathrm{I}+\phi\left(q+\tau_{\mathrm{b}} V\right)} .
$$

This would tend to give surges more readily in regions of high geothermal flux. Variations in the appropriate $\eta$ values from one ice mass to another will be dependent on the stress level as well as the temperature. It is expected that the use of suitable non-linear flow laws and octahedral stresses will clarify this.

The output for the programme includes profiles of other features of the ice mass such as base stress, longitudinal stress, longitudinal strain-rate, $\tau_{\mathrm{c}}, \tau_{\mathrm{c}}{ }^{\star}, V, \tau_{\mathrm{b}} V, V Z$, etc. The changes of these features during surges will be left to a separate paper in which a study of the matching of a variety of ice masses such as those of Table II will be presented.

\section{Conclusions}

The model presented here has been simplified to include just those features of an ice mass required to represent the essential physical processes of surging. These include the variations of ice thickness, stress, strain-rate and velocity along the central flow-line as a function of time. The information required for input include the bedrock and balance profiles, the flow properties of the ice, and the frictional lubrication factor.

Thus, with suitable two-dimensional parameterization, real glaciers, both surging and non-surging, can be modelled directly. A measure of the accuracy of the model can be obtained by a comparison of the calculated velocities and ice thicknesses with those of the real glaciers.

The model has considerable scope for improvement by increased generality and sophistication without changing the basic principles upon which it depends. The obvious extensions include generalization to three dimensions, use of more complex flow relations and octahedral stresses, and the development of more complex relations for base-stress lubrication. Even so, the present model has considerable flexibility in being able to match real surges in magnitude, speed, duration, and period.

By using the model to match real glaciers, important conclusions can be drawn on otherwise difficult problems such as the magnitude and distribution of the longitudinal stresses, the magnitude of the base stress, the sliding velocity, and the propagation of dynamic waves in glaciers during surging and non-surging conditions. The general problem of glacier sliding can be approached from a phenomenonological viewpoint with this model. Surging glaciers need not then be regarded as presenting any new difficulties, but rather as throwing considerable light on the processes of glacier sliding. This may then be used to improve the model to provide closer agreement with reality. 
Thus the model presented here may be regarded as the simplest model to include periodically surging glaciers as a natural sub-group of glaciers generally.

\section{Acknowledgements}

I am indebted to Mr Barry M. McInnes of the Meteorology Department of the University of Melbourne for obtaining the large number of computer runs required for preparing the diagrams. The advice of Dr D. Jenssen of the same Department on the model programming has also been much appreciated.

MS. received 21 December 1973 and in revised form I April 1974

\section{REFERENGES}

Budd, W. F. 1970. The longitudinal stress and strain-rate gradients in ice masses. Journal of Glaciology, Vol. 9,

No. 55, p. 19-27.
Budd, W. F. 1971. Stress variations with ice flow over undulations. Journal of Glaciolog, Vol. 10, No. 59, p.

Budd, W. W. , and Allison, I. F. In press. An empirical scheme for estimating the dynamics of unmeasured glaciers. [Paper presented at the International Union of Geodesy and Geophysics XV General Assembly, Moscow, 1971.]

Budd, W. F., and Jenssen, D. In press. Numerical modelling of glacier systems. [Paper presented at the International Union of Geodesy and Geophysics XV General Assembly, Moscow, 1971.]

Budd, W. F., and McInnes, B. J. In press. Modelling periodically surging glaciers. Science.

Budd, W. F., and Radok, U. I971. Glaciers and other large ice masses. Reports on Progress in Physics, Vol. 34,

No. I, p. 1-70.
Campbell, W. J., and Rasmussen, L. A. 1969 . Three-dimensional surges and recoveries in a numerical glacier model. Canadian Journal of Earth Sciences, Vol. 6, No. 4, Pt. 2, p. 979-86.

Campbell, W. J., and Rasmussen, L. A. 197c. A heuristic numerical model for three-dimensional time-dependent glacier flow. (In [Union Géodésique et Géophysique Internationale. Association Internationale d'Hydrologie Scientifique.] [International Council of Scientific Unions. Scientific Committee on Antarctic Research. International Association of Scientific Hydrology. Commission of Snow and Ice.] International Symposium on Antarctic Glaciological Exploration (ISAGE), Hanover, New Hampshire, U.S.A., 3-7 September 1968, p. 177-90.)

Carbonnell, M., and Bauer, A. 1968 . Exploitation des couvertures photographiques aériennes répétées du front des glaciers vêlant dans Disko Bugt et Umanak Fiord, juin-juillet 1964. Meddelelser om Grenland, Bd. 173 ,

Nr. 5.
Desio, A. 1954. An exceptional glacier advance in the Karakoram-Ladakh region. Journal of Glaciology, Vol. 2, No. 16 , p. $383-85$.

Dolgushin, L. D., and Osipova, G. B. 1971. Novyye dannyye o pul'satsiyakh sovremennykh lednikov [New data on the recent glacier surges]. Materialy Glyatsiologicheskikh Issledovaniy. Khronika. Obsuzhdeniya, Vyp. 18, p. $191-218$.

p. 19I-218.
Dolgushin, L. D., and Osipova, G. B. In press. Glacier surges and the problem of their forecast. [Paper presented at the International Union of Geodesy and Geophysics XV General Assembly, Moscow, 1971.]

Hodge, S. M. 1972. The movement and basal sliding of the Nisqually Glacier, Mount Rainier. Seattle, University of Washington, Dept. of Atmospheric Sciences.

Hoinkes, H. C. 1969. Surges of the Vernagtferner in the Otztal Alps since 1599. Canadian Journal of Earth Sciences, Vol. 6, No. 4, Pt. 2, p. 853-61.

Kamb, W. B. 1970. Sliding motion of glaciers: theory and observation. Reviews of Geophysics and Space Physics, Vol. 8, No. 4, p. $673-728$.

Lliboutry, L. A. 1958[a]. Contribution à la théorie du frottement du glacier sur son lit. Comptes Rendus Hebdomadaires des Séances de l'Académie des Sciences (Paris), Tom. 247, No. 3, p. 318-20.

madaires des
Lliboutry, L. A. 1958[b]. Ondes cinématiques sur un glacier et glissement sur le lit. Comptes Rendus Hebdomadaires des Séances de l'Académie des Sciences (Paris), Tom. 247, No. 1, p. 114-16.

Lliboutry, L. A. 1964. Sub-glacial "supercavitation" as a cause of the rapid advances of glaciers. Nature, Vol. 202, No. 4927 , p. 77.

Lliboutry, L A $1968[a]$. General theory of sub-glacial cavitation and sliding of temperate glaciers. Fournal of Glaciology, Vol. 7 , No. 49, p. $21-58$.

Lliboutry, L. A. 1968[b]. Théorie complète du glissement des glaciers, compte tenu du fluage transitoire. Union de Géodésie et Géophysique Internationale. Association Internationale d'Hydrologie Scientifique. Assemblée générale de Berne, 25 sept. $\rightarrow$ oct. 1967 . [Commission de Neiges et Glaces.] Rapports et discussions, p. 33-48.

de Berne, 25 sept. 7 oct. 1967 . [Commission de Neiges et Glaces.] Rapports et discussions, p. 33-48.
Lliboutry, L. A. 1969. Contribution a la theorie des ondes glaciaires. Canadian Journal of Earth Sciences, Vol. 6, No. 4, Pt. 2, p. 943-53. 
Meier, M. F. 1968. Calculations of slip of Nisqually Glacier on its bed: no simple relation of sliding velocity to shear stress. Union de Géodésie et Géophysique Internationale. Association Internationale d'Hydrologie Scientifique. Assemblée générale de Berne, 25 sept.-7 oct. 1967. [Commission de Neiges et Glaces.] Rapports et discussions, p. 49-57.

Meier, M. F., and Post, A. S. 1969. What are glacier surges? Canadian Journal of Earth Sciences, Vol. 6, No. 4, Pt. 2, p. $807-17$.

Nye, J. F. 1969. A calculation of the sliding of ice over a wavy surface using a Newtonian viscous approximation. Proceedings of the Royal Society, Ser. A, Vol. 311, No. 1506, p. 445-67.

Nye, J. F. 1970. Glacier sliding without cavitation in a linear viscous approximation. Proceedings of the Royal Society, Ser. A, Vol. 315 , No. 1522, p. $381-403$.

Post, A. S. 196o. The exceptional advances of the Muldrow, Black Rapids and Susitna Glaciers. Journal of Geophysical Research, Vol. 65, No. 11, p. 3703-12.

Post, A. S. 1966. The recent surge of Walsh Glacier, Yukon and Alaska. Fournal of Glaciology, Vol. 6, No. 45, p. $375^{-81}$.

Post, A. S. 1969. Distribution of surging glaciers in western North America. Fournal of Glaciology, Vol. 8, No. 53, p. 229-40.

Shumskiy, P. A. 1965. Theory of glacier variations. Fournal of Glaciology, Vol. 5, No. 40, p. 51 5-1 7. [Letter.]

Stanley, A. D. 1969 . Observations of the surge of Steele Glacier, Yukon Territory, Canada. Canadian Journal of Earth Sciences, Vol. 6, No. 4, Pt. 2, p. 819-30.

Thorarinsson, S. 1969. Glacier surges in Iceland with special reference to the surges of Brúarjökull. Canadian Journal of Earth Sciences, Vol. 6, No. 4, Pt. 2, p. 875-82.

Weertman, J. 1957. On the sliding of glaciers. Journal of Glaciology, Vol. 3, No. 21, p. 33-38.

Weertman, J. I962. Catastrophic glacier advances. Union Géodésique et Géophysique Internationale. Association Internationale d'Hydrologie Scientifique. Commission des Neiges et des Glaces. Colloque d'Obergurgl, 10-9-18-9 1962, p. $3^{\mathrm{I}-39}$.

Weertman, J. 1964. The theory of glacier sliding. Journal of Glaciology, Vol. 5, No. 39, p. $287-303$.

Weertman, J. 1967. An examination of the Lliboutry theory of glacier sliding. Journal of Glaciology, Vol. 6, No. 46 , p. $489-94$.

Weertman, J. 1969. Water lubrication mechanism of glacier surges. Canadian Journal of Earth Sciences, Vol. 6, No. 4 , Pt. 2, p. 929-42. 